ISSN 2081-8130

DOI: $10.14746 /$ prt.2015.4.2 www.praktykateoretyczna.pl

\title{
TOWARDS A GLOBAL REgIME OF HigHER EDUCATION
}

\author{
PAOLO DO
}

\begin{abstract}
This paper rethinks the spatialization of educational institutions at the global level, scaling and rescaling the space of the university as an inclusive process that makes academic knowledge production something heterogeneous, complex and composite, and proposing a regime for the higher education system based on a stratified relationship that is asymmetrical and geographically displaced. Moreover it outlines the "new" political economy of knowledge, which is a particular mechanism in contemporary capitalist production, capable of creating an artificial scarcity of knowledge by means of hierarchies, and reproducing the classical law of value in a regime based on abundance instead of scarcity.
\end{abstract}

Keywords: Global University, multiscalar space, hierarchies, new political economy of knowledge, cognitive capitalism 
The transformation of higher education and its institutions is increasingly related to social differentiation, bringing and multiplying, rather than mitigating, hierarchies and differences in the global space. This creates a jagged entanglement of regions, multiplication of borders, frontiers of capital, global cities and zones of interaction that continuously overlap, struggle and coexist one with the other.

Therefore, to think about higher education nowadays we have to place the research in a less stale articulation of focal points that express a multiplication of powers and entangling of spaces within a heterogeneous temporal dimension. While the classical distinction between centre/periphery has been eroded, we are living in an original horizon in which the hierarchies of the past are dislocated to assume new forms. From this perspective, the former divisions have not disappeared nor have they been annulled; rather they are redefined and maintained in a new framework: the classical divides have morphed into a multiplication of centres and been displaced into a fragmented geography of asymmetrical relations.

These changes we are experiencing require a new logic and methodological resources to examine the global space beyond the classic dichotomies of modernity: the West/East, North/South, tradition/modernity or the opposite identities that are first of all historical and political. Methodologically, I propose to rethink the space of higher education at the global level through the deconstructive approach of Naoki Sakai, which I find a useful tool for dislocating the notion of the West. According to him, the concept of the West cannot refer to a specific geographical definition but refers to something historical and having to do with hegemony and power relationships that are never given once and for all (Sakai 1997). In the same vein, C. J. W.-L. Wee argued that economic and political power has shifted away from a geographical location called the "West" to a less identifiable position in the "globe" (Wee 2007). Following this analysis, it is possible to describe the dispersal of the "West" into the "globe". The West, considered as a power relationship, is not homogeneous but is a composition of many variables, none of them remaining constant in time or space. The notion of the West "can never be a unity: it is a composite or assemblage of disparate contexts" (Sakai 2000). This approach shifts our attention from the binary contraposition to multiple dislocations. The global scale, rather than designating a bounded physical territory, expresses the gradient and the vertical positions of subjects-in-relation: in this context, I propose the spatialization of the global regime of the higher education system as a hierarchical relationship that is asymmetrical and geographically displaced.

Another distinctive feature comes from the methodology proposed by Kuan Hsing Chen (2010). This author, echoing the research of Ashis Nandy on Indian modernity, suggests that we consider the West as bits and fragments that intervene in local social formations in 
a systematic, but never totalizing, way: thus the local formation of modernity carries essential elements of the West, but does not fully envelop it.

Having once recognized the West as consisting of fragments internal to the local, it is possible to rethink the global space in the form of fragmented pieces, its North having entered the same history as the South, with each becoming a part of the other, but not in a linear manner. Following this strategy advanced by Kuan Hsing Chen, the North and the South, as well as the East and the West, are not united or uniform. The approach suggests that instead of being opposed, the same relationship is constituted by "bits and fragments" as variables with which to observe - from a non-European/Eurocentric point of view - the political definition of knowledge production through its spatiality.

Nonetheless, this articulation of fragments and bits in a heterogeneous space risks appearing as a sort of enigmatic space or subject; quite the contrary, at the instant when this displacement emerges we can discern a new set of power relations shaping a different image of the global territories. In this sense, it is worth considering the words of Stuart Hall:

\footnotetext{
"Colonization [...] had to be understood then, and certainly can only be understood now, in terms, not only of the vertical relation between colonizer and colonized, but also in terms of how these and other forms of power-relations were always displaced and decentred by another set of vectors" (Hall 1996, 250).
}

Starting from this evocative reflection on power-relations, it is possible to explore the global space of higher education through a relatively new "geopolitical dispositive" of knowledge production that is the Regional Hub of Education (RHE), which is profoundly changing the landscape of higher education in the regions of Asia and the Middle East, as well as at the global level. The Regional Hub of Education and the public policies devoted to its establishment have flourished in a period of no more than ten years, grounding the liberalization and deregulation of educational services promoted by the WTO and the eduGATS agreements (Knight 2002, 2006; OECD 2007; Mazzarol \& Hosie 1996; OECD 2003, 2006, 2010). This process is distinguished by the emergence of new polarities that are influencing the global geography of knowledge production (Chan \& Ng-Pak 2008). They are an articulated set of vectors able to decentralize and to displace, both spatially and temporally, relationships of dependence and its asymmetries rooted in the global space.

According to Sajitha Bashir, current literature defines the RHE as an economic dispositive based on "exporting higher education services by recruiting overseas students" (Bashir 2007). Today in Asia examples of this kind of hub are the city-states of Singapore and Hong Kong, while at the same time Malaysia is orienting its policies in this direction (Down 2009). The RHE is a crossroads, a contact zone, an articulated set of vectors able to decentralize and displace, both geographically and temporally, relationships of dependence and its 
asymmetries, relations of power rooted in the colonial system of dependence. The RHE produces new forms of socioeconomic stratification, a regional differentiation through globalization of knowledge production. Within the growing intra-regional mobility of the global workforce, the global regime of higher education emerges as a powerful dispositive of "postcolonial differentiation", namely the stratification and hierarchy of a skilled workforce within the global labour market. In this original and powerful management of the increasingly qualified workforce, the classic colonial divide has morphed into a multiplication of centres and been displaced into a fragmented geography of asymmetrical relations managed through knowledge production.

Nowadays higher education and its internationalization form an important dispositive to reconfigure and manage the complex displacement of centre/periphery, having the same force, or even more, as those of gender and race in the cartography of the present, wherein knowledge production becomes spatially dispersed and globally integrated. Knowledge, geographically embedded, defines the order of the current post-colonial space, while the global university is a device that articulates this heterogeneity by managing hierarchies, segmentation and the imbalances of the population and the global workforce.

Regarding the issue of the language medium of instruction, the so-called Global English and its use in the universities reveals the emergence of new socioeconomic stratifications. It does this through education and knowledge production that have come to constitute a powerful biopolitical dispositive assuming control and governance of populations on a global scale, redefining in an original way the colonial relations of the past and its asymmetries. In the words of Angel Lin:

\footnotetext{
"The English-dominant education system seems to have produced an elite bilingual social group whose cultural identities are constructed through their successful investments in an English-medium education, a mastery of the English language and their familiarity with and membership in English-based modern professional institutions (e.g. the various English-based professional associations of accountants, lawyers, doctors and engineers, and English- mediated professional accreditation mechanisms). At the same time, alongside the production of these English-oriented successful modern professional, cosmopolitan subjectivities, the English-dominant education system also seems to be producing another much larger group of subalterns, whose own understanding of themselves and their future life trajectories are greatly delimited by a neocolonial, complex capitalist modern regime of culture that seems to have almost stripped them of any possibility of constructing a valuable, legitimate, successful self with other non-English-based cultural resources" (Lin 2005, 51).
} 
For many the label "global university" means nothing except a growing global conformity in knowledge production and the imperatives delivered to institutions of higher education, borne out by the inevitable "time-space compression" entailed in neoliberal capitalism (de Barry 2010). This understanding of the global university as a gradual homogenization of historical and social differences, a progressive cultural "convergence", describes the changes in higher education in non-Western countries as a kind of transition from an "inadequate" national educational system towards another "more advanced" one. The same process is described as driven by an idea of modernization through different historical stages of development that considers the Anglo-Saxon and European stage to be the final and ultimate step. This "convergence" approach draws to a great extent on contemporary literature that attempts to describe the changes in countries like China, Brazil, India and BRICS in general, understanding educational changes as synonymous with "westernization", while the meaning of modernity is nothing more than "Americanization" or "Europeanization" (de Barry 2010). The changes to knowledge are seen through the lens of its "corporatization", while the achievement of the "university of excellence" is associated with the American or the Anglo-Saxon model: the "best way" to standardize university and to homogenize cultures as a result of globalization (QiLi 2010).

This kind of approach explains the current changes as results of a progressive and tendential reduction of differences towards some uniform level and requires, first of all, an internal logic to account for this trend as an endogenous reference to capitalistic valorization (for a critique of the comparative studies approach see Krishnaswamy \& Hawley 2008; Sanyal 2007; Shavit et al. 2007; Bravo 2001). Moreover, the same ratio assumes a successive approximation towards a unique, "universal" and well-defined model embodied by one (or more) societies involved in the process: in the case of higher education, the Anglo-Saxon and American societies. Thus, the university systems of different countries are often defined simply and exclusively in terms of the elements similar and comparable to the "gold standard" of "the West", this latter considered the basis on which to compare any changes and metamorphoses worldwide.

Several analyses of the transformation of higher education in Asia, Africa or Eastern Europe by international agencies such as WES (World Education Service), IAO (International Association of Universities), UNESCO (United Nations Educational, Scientific and Cultural Organization), and World Bank among others assume, implicitly or explicitly, the model of knowledge production of the West both as an instrument of measurement and a point of reference: in other words it is a sort of ideal-type that relegates the necessary differences into a posteriori speculation, based on deviations from defined patterns. The expressions "battle for 
excellence" (Enserink 2007), "positional arms race" (Winston 2000), and "reputation race" describe the extent to which a given university is close to, far away from or catching up with the Western standard. Using the "one-size-fits-all" benchmark, with which one evaluates academic excellence by using the global university ranking, the institutions of higher education are primarily ranked according to how far they deviate from the "best"; that is, the extent to which universities are at variance with Harvard (Ellen 2011).

I propose another point of view and other categories for the current globalization beyond the classic homogeneous areas, as well as beyond the European and American university system, towards the multiscalarity of the global university. With this notion, I want to refer to the ordering of sociospatial units within multiple hierarchies of power, whereby the scale organization of a university lies in the vertical differentiation and redifferentiation of social relations. The contemporary spatial transformations of knowledge production have not generated a unidirectional process of globalization, decentralization, regionalization, or localization in which a single scale -be it global, regional or local - is replacing the national scale as the primary level of political and economic coordination (Brenner 2011). Indeed, what is emerging is a set of interactions irreducible to the mirroring identity of the West and the East, as well as of Europe and Asia, which are produced between non-localizable connections, actions at a distance, systems of replay, resonances and echoes, 'objective chances, signs, signals and roles which transcend spatial locations and temporal successions' (Deleuze 2004). These emerging interactions and articulations constitute what I call the global university: an inclusive process that makes academic knowledge production something heterogeneous, complex and composite - characterized by actors different and hybrid, private and public, institutional and non-institutional. The global university is a point of discontinuity with academic institutions both of the past and present; it is a point of spatial multiplicity in the midst of the transformation of educational policies by which it is possible to identify the participation of newly emerging actors of academic knowledge production, new players within a different logic at both regional and transnational levels, assembled in a non-linear manner at times, and in correspondence with frictions, conflicts and contradictions. The global university is characterized by the presence of private corporations and multinationals, transnational and national agencies intertwined in an original relation where institutions such as the WTO and the GATS have been agitating for the liberalization of services, in addition to agencies like UNESCO and the World Bank, and have become increasingly important for managing the mobility of scholars, students and curricula in a new interdependent and conflictual network.

The global university is a multifaceted spectrum characterized by heterogeneous subjects with positions, forces and different roles that are mutually interdependent. It is possible to observe different drivers to which correspond notable players and actions that meet, clash and are assembled to shape current knowledge production. The globalization of higher 
education is a composite weaving of relational, cognitive resources (access to data, citation analysis and scientometrics, information from global ranking and branding) and cooperative networks which includes not only the physics of its spatial dimension, but also the connectivity and interconnection between different institutions, corporate agencies, public and private players and services (Olds 2007, 2010). This original educational institution also includes "temporal" assets: links and networks that are not permanent but transitory, partial and capable of being continuously updated (Bologna 2010). We can clearly observe this in the geography drawn by the increasing short-term mobility of students, involving several institutions of several countries at the same time (Teichler 2007) of which the "joint degree program" and "dual or double degree program" are perhaps its most distinctive elements. At the same time, the longterm mobility of students is taking original paths and finding new destinations, so that an original geography of knowledge production is rapidly emerging: new players in Asia and the Middle East have entered the global education market with declared ambitions to compete with the US, the UK, New Zealand and Australia. In this new scenario, instead of the disappearance of boundaries, knowledge production at the global level is experiencing a multiplication of borders, which are increasingly dynamic and flexible: they have become mobile despite not losing their control over specific and determined places.

The global university is characterized by continuous overlapping and differentiations, assemblages and combinations, with influences in the distance and effects within the knowledge production deployed in a diffuse environment, instead of being confined to the narrow boundaries of the educational institutions. Within the mutual interaction of different players at the national, regional and global scale, the "ivory tower" has been transformed from an isolated place to an articulated and complex system: a constellation or archipelago of different actors, technologies and devices.

\section{III}

The current transformation of the university and knowledge production brings about space beyond the classical polarization and dichotomies of modernity: the West/East or North/South rather than national/global; the first, second and third world or the opposite identities that are first of all historical and political. The global space we are living in has shifted from the classical idea of unity and space/time homogeneity - an inherent feature of the Western nation-state and its historiography that considers "time" and "space" smooth, empty and homogeneous areas preserving a rigid sameness - to a multiplication of powers and entangling of spaces within a heterogeneous temporal dimension (Chakrabarty 2008).

The multiscalar space of the global university is constituted by different zones of relative and absolute surplus value, real and formal subsumption, frictions, imbalance, and 
a new form of exploitation and hierarchies. Far from being characterized by homogeneity, it is deeply heterogeneous. It is in this way that capital itself, affirming its command, works through the articulation and assemblage of multiple determinations that are not reducible to any single logic (Collier \& Ong 2008). Its temporality is emergent, which means that it does not always involve new forms, but rather methods that are shifting, in formation, or at stake. Through these different spaces and times it is possible to perceive what Aihwa Ong defines as postdevelopmentalism:

"a more dispersed strategy that does not treat the national territory as a uniform political space. Market driven logic induces the coordination of political policies with the corporate interests, so that developmental decisions favour the fragmentation of the national space into various non-contiguous zones, and promote the differential regulation of a population who can be connected to or disconnected from global circuits of capital” (Ong 2006, 77).

So far, the assemblage implies heterogeneity, a contingent and unstable temporality of surfacing, whereas global refers to an inherent and seamless tension. This concept is useful for framing economic processes situated in different spaces and times: a dispersed strategy that does not treat a territory or a region as a uniform political space, while the fragmentation of the national space into various non-contiguous zones promotes the differential regulation of a population that can be connected to or disconnected from the global circuits of capital.

One approach to understanding the increasing heterogeneity and multidimensionality of the global space is the category of cognitive capitalism, elaborated in the mid-90s by the journals Multitude in France and Posse in Italy, which unfold a sort of exposition universelle of the different labour regimes that characterize the current neoliberal capitalism ${ }^{1}$. Carlo Vercellone stressed the centrality of knowledge to the long-term dynamics of capital, identifying a periodization composed of three stages of the capitalist division of labour and the role of knowledge. The first was the stage of formal subsumption, comprising the period between the beginning of the sixteenth and the end of the eighteenth century, characterized by the centrality of manufacturing, based on the models of production of the putting-out system, the supremacy of craftsmen's knowledge, and the pre-eminence of the mechanism of accumulation of a mercantile type. The second was the stage of real subsumption that starts with the first industrial revolution and is characterized by the process of polarization of knowledge, which is

\footnotetext{
1 The name "cognitive capitalism" refers to the dialectic relationship of its elements. According to Carlo Vercellone the word "capitalism" defines the enduring element in the change of the structural invariants of the capitalist mode of production: in particular, the driving role of profit and the wage relation or, more precisely, the different forms of dependent labour on which the extraction of surplus labour is founded. The word "cognitive" emphasizes the new nature of the conflictual relation of capital and labour, and of the forms of property on which the accumulation of capital rests.
} 
expressed in the disqualification of the labour of execution and the overqualification of a minoritarian component of labour power, destined for intellectual functions. This stage was characterized by the reduction of complex labour into simple labour and by the incorporation of knowledge into fixed capital. Finally, the third stage in Vercellone's scheme begins with the crisis of Fordism and its division of labour, marked by the driving role of "the production of knowledge by means of knowledge" connected to the increasingly immaterial and cognitive character of labour (Vercellone 2007).

Starting from this theoretical framework of the change in the capital/labour relation, I affirm that these three different layers do not represent a temporal linear sequence or a chronological series. Quite the opposite: they perform as a synchronic intersection, a partial syncretism that transforms this sort of evolution into a heterogeneous coexistence of different capital relations. It is the coexistence of these particular elements, rather than their temporal linear sequence, that characterizes the geography of the contemporary relations of capital worldwide which, far from being marked by homogeneity, is profoundly heterogeneous, in both its spatial and temporal axes. In this contest it might be useful to recall the debate on the varieties of capitalism to stress the issue of difference and global capitalism, thus problematizing the similar possibility of a unitary definition of capitalism (Chalcraft 2005; Jessop 2012; Hall \& Soskice 2001; Crouch 2005; Streeck 2009).

Delocalization, transnational education and export orientation as well as a multiplicity of modes of work comprise this scenario, resulting in a sort of geographic coexistence of low and high-intensity value extraction.

At the same time there is no lack of differentiation among different forms of surplus extraction, nor is the end of inequality in sight. Reshaping the temporal and chronological axis into a synchronic horizon does not mean that heterogeneity is synonymous with undifferentiation, whereby one could be a substitute for another: in coexistence and co-presence, indistinction does not mean the impossibility of making a distinction. On the contrary, it is possible to observe how one particular sector of production is organized by the timing and needs of another, and how so-called cognitive labour is rescaling and ranking the so-called neoTaylorist occupations. Knowledge production could be regarded as the particular production which determines the position and importance of all the others: it is as though the light of a particular sector were cast upon everything, tinting all other colours and modifying their specific features; or as if a special ether determined the specific gravity of everything found in it, as Marx described it in his Grundrisse of 1857. 


\section{IV}

Some say the university is becoming more like a global corporation, while market forces drive the current transformation of higher education and its progressive expansion (Varghese 2001; Biao \& Shen 2009; Fran Van Vught 2008; Shavit et al. 2007; Zhang 2009; Cobalti \& Schizzerotto, 1994). My position is that the university is not just following, but is prefiguring the global economy after the financial crisis, due to the pivotal characteristic of knowledge.

Worldwide, current policies of access to education express the persistence of the principle of scarcity: the raising of fees reveals a general intensification of the costs of studying. Beyond national and regional differences as well as singular local specificities, the relation between the university institution and market forces, privatization trends and the increasing level of tuition fees seems to be the main framework of the commodification of education driven by a profit-oriented logic. The expansion of higher education is characterized not only by the presence of private universities. The face of the present change is illustrated by public universities that, despite being public, are for-profit oriented and "corporate-like", by this means overcoming the classical distinction between the public and private sectors (Francis 2001; Sassen 2008). New assemblages and institutional hybridizations are the result of the complex transformation of the university's funding system, caused by the progressive and constant defunding of the education sector by the nation-state (Psacharopoulos 1994; Zhong \& Zhu 1998). The intricate institutional heterogeneity that emerges from these studies underlines how today the expansion of higher education is parallel to a general increase in its costs to the student (the "consumers") and their families.

This process of commodification related to the expansion of education involves, first of all, a sort of hybridization between education inshore and offshore, for-profit and non-forprofit sectors as well as between public and private providers, which transforms the general relation between public and private into something extremely ambiguous, indeed fluid, alongside a continuum of gradations that is replacing the sharp distinctions among them. We are facing an articulated interaction of public and private, a complex interdependence that comes with a proliferation of hybrid educational institutions.

In particular, since the global financial crisis, the public universities of several countries of the Global South and East Asia have become more and more oriented towards commercial activities. Despite still being public, programs, curricula and policies are transforming universities into actors looking for profits; the reduction of public resources has forced universities towards a pro-business orientation, eroding the classical liberal distinction between private and public (Mohrman 2008). Take the case of the associate degree programs (AD) introduced in 2001 in Hong Kong: the particularity of this kind of degree is that, despite being provided by public universities, they are entirely paid for by students, and are therefore self- 
financed. Since 2001, several public university campuses in Hong Kong are thus inhabited by "regular" students as well as by "associate" students: two different populations, who follow different kinds of courses and have different expectations, but who are living at the same university

The emergence of original assemblages of universities that are no longer strictly public or private in traditional terms opens up a new device for the management of knowledge production.

The valorization of knowledge transforms education into a commodity that is quite specific and particular, a positional good (Hirsh 1977) that is hierarchical in character, according to which some forms are more valuable than others: the value of the degree depends on the ranking and its position within the national and international hierarchy. This hierarchy sets up filters whereby a degree from $\mathrm{X}$ university or $\mathrm{Y}$ country is worth less than the same degree from another university or country, the difference being reflected in wage differentiation.

As also affirmed by Ernesto Tavoletti, the positional goods are probably the most important goods produced in the educational market:

\footnotetext{
“The HE system [...] introduce(s) a hierarchy between universities, making the system coherent with the existence of positional goods. Shifting positional good competition from level of qualification to universities would allow a modern and widespread policy for HE without [...] logical contradiction" (Tavoletti, 2009).
}

The positional value of the "educational credential" in the hierarchy of knowledge production transforms education into something that is not merely scarce, like all economic commodities, but scarce in relative terms. The change from an abundant good to a commodity that is relatively scarce is made possible by stressing the relative value of knowledge associated with its relative position in the hierarchical order.

In other words, hierarchy makes the commodification of education possible, while the same valorization of knowledge considers value not absolute but relative, something higher or lower compared to another; the value of knowledge is less and less independent and more and more measured by its position in relation to another.

In addition to patents, copyrights and the pervasive hegemony of intellectual property, the classical tools that turn knowledge into a scarce resource, hierarchies are the dispositive of the new political economy of knowledge; with this notion I refer to the particular mechanism of contemporary capitalist production that reproduces the classical law of value in a regime based on abundance instead of scarcity. The "new" political economy of knowledge creates an artificial scarcity of knowledge by means of hierarchies, while at the same time the value of knowledge, far from being the result of its natural scarcity, is the outcome of the limits established to prevent access to it. The scarcity of knowledge, which constitutes its capitalistic 
value, is therefore artificial in nature and comes from the ability of this or that power to limit and regulate its access. In fact, according to authors such as Carlo Vercellone (2006), Enzo Rullani (2004), and Y. M. Boutang (2002), education and knowledge exceed the "objective" criteria of exchange in the classical economic theory of value because they are by no means scarce resources. Quite the opposite: they are abundant and not consumed through use, but enrich themselves through being shared and diffused within society. Knowledge possesses a multiplicative power based on sharing, so that widening the pool of use and re-use of what one knows can reduce redundancies (Rullani 2001): the more you share, the more knowledge becomes abundant. Hardt and Negri defined the same category of the "common" through those results of social production that are necessary for social interaction and further production, such as languages, codes, information, affects, and so forth (Negri \& Hardt 2009).

While stratification and segmentation introduce a "logic of scarcity" at the ground level of the new political economy of knowledge, it is possible to associate this with a "positional rent" for a university degree that changes according to the position of institutions within the vertical hierarchy of the educational system.

One might say that geography and language are, nowadays, the factors that differentiate and influence this kind of rent in the post-colonial geography of knowledge production: the language of education and knowledge production, and the geographical position of a university reflect geopolitical positions of historical and social imbalances, revealing a global order composed of old and new hierarchies. Knowledge production, geographically rooted, strengthens and multiplies the historical differences marking the asymmetries of the post-colonial order. In the "new" political economy of knowledge, the processes of the capitalistic valorization of education are increasingly dependent on extraeconomic factors, while the social and historical aspects form the condition of possibility for the same capitalistic valorization.

\section{$\mathrm{V}$}

The progressive differentiation of educational institutions on the regional, national and global scale, within the new massification and internationalization of higher education parallel to its valorization, refers to the proliferation of hierarchies based on a multiplication of internal and external boundaries. Differences, both at the micro and macro levels, are organized, managed and defined as asymmetries and inequalities by capitalistic command.

While it is possible to distinguish between top and second-tier universities, between different degrees of reputation, qualities of knowledge and its institutions, the global rankings of the university influence the "architectural shape" of the educational system, organizing it through the spatially distributed differences of its elements. 
Discipline always involves a heterogeneous environment managing and organizing a multiplicity, fixing its points of implantation as lateral or horizontal, vertical and pyramidal trajectories, its hierarchy, and so on (Foucault 2009). From this point of view the global ranking of universities such as the Academic Ranking of World University (ARWU) or the Quacquarelli Symonds World University Ranking (QS), rather than the Times Higher Education World University Thomson Reuters (THE), can be regarded as a sort of "disciplinary management of multiplicities in space", with the heterogeneity organized according to the principles of hierarchy, precise communication of relations of power, and functional effects specific to this distribution (Foucault 2009).

This stratification and these hierarchies seem fairly flexible and plastic, resembling a continuous relation never given once and for all. In fact, the order in which the heterogeneous space of knowledge production is defined, the relationship between its constituent elements, as well as the divisions and the asymmetries of the educational system, are quite mobile and based on the variable results of bibliometrics and informetrics. Rankings are continually updated: new versions are released every year to acknowledge the shifting positions of each university, their performance improvement or decline; comparisons are made and historical trends analysed. It emerges that hierarchy in the educational system is totally transformable precisely because it is based on results that change continuously.

At the same time, there are also rigid segmentations which shape the hierarchy of global knowledge production: higher education is intertwined with the historical and political aspects of the post-colonial temporality. The social and political asymmetries attributable to the colonial period persist in forms and dimensions despite being transformed, displaced and multiplied by growing intra-regional mobility. The global dimension of the university is intertwined in rigid contrapositions that characterize the hierarchies of knowledge production. The same rigidity is emerging in academic publishing based on journals largely overbalanced in favour of the Anglo-Saxon countries and favouring the codified "Standard British English" (SBE) and "General American English" (GAE). By means of this formal code, through which knowledge circulates, reproduces and reflects the asymmetry of West/the Rest (Hall 1996), while knowledge production fixes positioning and hierarchies that are not only linguistic but geographical, historical and political, the imbalances of history and the colonial present are reflected in the production of knowledge.

It is possible to outline a particular "global regime of higher education", that is to say, an articulation of forces and contradictions, asymmetries and differential positions constituted by the coexistence of segmentations that are both flexible and rigid: the first are based on informatics and data analysis; the second, on the contrary, have a social, historical and political basis. They do not only coexist but transform themselves into one another, or cross over into 
one another; they are inseparable, they overlap, they are entangled in multiple and flexible divisions and rigid and dichotomous segmentations.

The notion of the regime, from the Latin regimen regiminis, stresses the multiplication of actors that come to the fore of the production of knowledge and the balance of forces within the governance of the skilled workforce at the global level. Contrary to the classical systemtheories, it includes a multitude of actors whose practices relate to each other without, however, being ordered in the form of a central logic or a fixed frame (Tsianos \& Karakayali 2010). The idea of a "global regime of higher education" implies a space of negotiating practices, providing a framework wherein understanding the actions and effects of different actors and subjects, allowing room for gaps, ambiguities and outright strain (Sciortino 2004), thus emphasizes the multiscalarity of the global university. 


\section{References}

Bashir, Sajitha. 2007. Trends in International Trade in Higher Education: Implications and Options for Developing Countries. Washington: World Bank working paper.

Biao, Xiang \& Shen Wei. 2009. "International Student Migration and Social Stratification in China”. Int. Journal of Educational Development 29(5): 513-522.

Bologna, Sergio. 2010. Le multinazionali del mare. Milan: Egea.

Boutang, Y. M. 2002. L'età del capitalismo cognitivo. Verona: Ombre Corte.

Brenner, Neil. 2011. "The Urban Question and the Scale Question. Some Conceptual Clarifications". In Locating Migration. Rescaling Cities and Migrants, ed. by Nina Glick Schiller \& Ayse Çaglar. New York: Cornell University Press.

Chakrabarty, Dipesh. 2008. Provincializing Europe: Postcolonial Thought and Historical Difference. Princeton: Princeton University Press.

Chalcraft, John. 2005. "Pluralizing Capital, Challenging Eurocentrism: Toward post-Marxist Historiography". Radical History Review 91: 13-39.

Chan, David \& Pak Tee Ng. 2008. "Similar Agendas, Diverse Strategies: The Quest for a Regional Hub of Higher Education in Hong Kong and Singapore". Higher Education Policy 21(4): 487-503.

Cobalti, A. \& A. Schizzerotto. 1994. La mobilità sociale in Italia. Bologna: Il mulino.

Collier, J. Stephan \& Aihwa Ong (ed.). 2008. Global Assemblages: Technology, Politics, and Ethics as Anthropological Problems. New York: John Wiley \& Sons.

Crouh, Colin. 2005. Capitalist Diversity and Change. Recombinant Governance and Institutional Entrepreneurs. Oxford: Oxford University Press.

De Barry, Brett (ed.). 2010. Universities in Translation: The Mental Labour of Globalization. Hong Kong: Hong Kong University Press.

Deleuze, Gilles. 2004. Difference and Repetition. Trans. Paul Patton. London: Continuum International Publishing.

Deleuze, Gilles \& Felix Guattari. 1987. A Thousand Plateaus, Capitalism and Schizophrenia. Trans. Brian Massumi. Minneapolis-London: University of Minnesota Press.

Down, Dale. 2009. Malaysia: Future hub of international education? (Available at: www.universityworldnews.com/article.php? story=20090903203756838; African

Countries recognize Malaysia as Education hub: www.my.news.yahoo.com/africancountries- recognise-malaysia-education-hub-says-educationist-033501057; last access December 1, 2010).

Enserink, Martin. 2007. “Who Ranks the University Rankers?” Science 317: 1026-1028.

Ferrari Bravo, Luciano. 2001. Dal Fordismo alla globalizazæione. Rome: Manifestolibri.

Foucault, Michel. 2009. Security, Territory, Population: Lectures at the Collège de France 1977-1978. London: Picador.

Francis, Corinna-Barbara. 2001. "Quasi-Public, Quasi-Private Trends in Emerging Market Economies: The Case of China". Comparative Politics 33(3): 275-294.

Hall, Peter A. \& David Soskice (eds). 2001. Varieties of Capitalism: The Institutional Foundations of Comparative Advantage. Oxford: Oxford University Press.

Hall, Stuart. 1996. "When Was 'the Post-colonial'? Thinking at the Limit". In The Post-colonial Question: Common Skies, Divided Horizons, edited by Iain Chambers \& Lidia Curti. London: Routledge 
Hardt, Michael \& Antonio Negri. 2009. Commonwealth. Cambridge: Harvard University Press. Hazelkorn, Ellen. 2011. Rankings and the Reshaping of Higher Education. The Battle for World-Class Excellence. London: Palgrave Macmillan.

Hirsh, Friedrick. 1977. Social Limits to Growth. London: Routledge \& Kegan Paul Ltd. Inter-Asia Cultural Studies 10(2).

Jessop, Bob. 2012. "The Diversity and Variability of Capitalism". In Capitalist Diversity and Diversity Within Capitalism, C. Lane \& G. Wood (eds). London-New York: Routledge.

Knight, Jane. 2002. "Trade talk: an analysis of the impact of trade liberalization and the general agreement on trade in services on higher education". Journal of Studies in International Education 6(3): 209-229.

Knight, Jane. 2006. Higher Education Crossing Borders: A Guide to the Implications of the General Agreement on Trade in Services (GATS) for Cross-border Education. Paris: UNESCO.

Krishnaswamy, Revathi \& John C. Hawlay (eds). 2008. The postcolonial and the global. Minneapolis: University of Minnesota Press.

Lin, Angel. 2009. 'Critical, Transdisciplinary Perspectives on Language-in-Education Policy and Practice in Postcolonial Contexts: The Case of Hong Kong". In Decolonisation, Globalisation: Language-in-Education Policy and Practice, ed. by Angel Lin and Peter W. Martin. Clevedon: Multilingual Matters Ltd.

Marx, Karl. 1979. The Grundrisse. Trans. \& ed. by David McLellan. London: Harper \& Row Publishers.

Mazzarol, Tim \& Peter Hosie. 1996. "Exporting Australian higher education: Future strategies in a maturing market". Quality Assurance in Education 4(1): 37-50.

Mohrman, Kathryn. 2008. "The Emerging Global Model with Chinese Characteristics". Higher Education Policy 21(1): 29-48.

Negri, Antonio \& Carlo Vercellone. 2007. "Il rapporto capitale/lavoro nel capitalismo cognitivo". In Posse, La classe a venire. Rome: Manifestolibri.,

OECD. 2003. Internationalisation and trade in higher education. Paris: OECD Publishing.

OECD. 2006. "Globalisation and higher education". OECD Education Working Papers 8.

OECD; World Bank. 2007. Cross-border Tertiary Education: A Way towards Capacity Development. Paris: OECD.

Olds, Kris. 2007. "Global assemblage: Singapore, Western universities, and the construction of a global education hub”. World Development 35(6): 959-975.

Olds, Kris. 2009. “Association, networks, alliances, etc: making sense of the emerging global higher education landscape". Keynote Paper, 3rd Global Meeting of Associations of Universities.

Ong, Ahiwa. 2006. Neoliberalism as exception: mutations in citizenship and sovereignty. Durham: Duke University Press.

Psacharopoulos, George. 1994. "Returns to Investment in Education: A Global Update". World Development 22(9): 1325-1343.

QiLi, Lei. 2010. "From elitism to populism: the 'industrial' model and Chinese higher education". In Universities in translation: the mental labor of globalization, ed. by Brett de Barry. Hong Kong: Hong Kong University Press.

Rullani, Enzo. 2001. "Il capitalismo cognitivo del déjà vu”. In Posse. Rome: Manifestolibri.

Rullani, Enzo. 2004. Economia della conoscenza. Milano: Carocci editore. 
Sakai, Naoki. 1997. Translation and Subjectivity: On "Iapan" and Cultural Nationalism. Minneapolis-London: University of Minnesota Press.

Sanyal, Kalyan K. 2007. Rethinking capitalist development: primitive accumulation, governmentality and post-colonial capitalism. London: Routledge.

Sassen, Saskia. 2008. Territory, Authority, Rights: From Medieval to Global Assemblages. Princeton: Princeton University Press.

Sciortiono, Giuseppe. 2004. "Immigration in a Mediterranean Welfare State: The Italian Experience in Comparative Perspective". Journal of Comparative Policy Analysis: Research and Practice 6(2): 111-129.

Shavit, Yossi, Richard Arum, Adam Gamoran \& Gila Menachem. 2007. Stratification in higher education: a comparative study. Stanford: Stanford University Press.

Streeck, Wolfgang. 2009. Re-Forming Capitalism: Institutional Change in the German Political Economy. Oxford: Oxford University Press.

Tavoletti, Ernesto. 2009. Higher Education and Local Economic Development. Florence: Firenze University Press.

Teichler, Ulrich. 2007. The Changing Role of Student Mobility (Available at: portal.unesco.org/education; last access May 4, 2009).

Tisanes, Vassals \& Serhat Karakayali. 2010. "Transnational Migration and the Emergence of the European Border Regime: An Ethnographic Analysis”. European Journal of Social Theory 13: 373-387.

Varghese, N. V. (ed.). 2001. Impact of the economic crisis on higher education in East Asia: Country experiences. Paris: International Institute for Educational Planning, UNESCO.

Vercellone, Carlo. 2006. Capitalismo Cognitivo. Conoscenza e finanza nell epoca postfordista. Rome: Manifestolibri.

Vught, Frans van. 2008. "Mission Diversity and Reputation in Higher Education". Higher Education Policy 21: 151-174.

Winston, Gordon. 2000. The Positional Arms Race in Higher Education (Available at: www.econstor.eu/bitstream/10419/23501/1/DP-54.pdf; last access December 1, 2009).

Zhang, Jianxin. 2009. ASLAN Higher Education on the Road from Elite to Massification. Facing Global and Local Challenges: the New Dynamics for Higher Education. Asia-Pacific Subregional Preparatory Conference for the 2009 World Conference on Higher Education: 24-26 September 2008 Macao SAR, PR China.

Zhong, Binglin \& Chuanli Zhu. 1998. Higher Education in Transition Economies in Asia. Proceedings of the First Workshop on Strategies and Policies in Higher Education Reform in Transition Economies in Asia, Xi'an, China, 7-10 October. Bangkok: UNESCO. 
Paolo Do - is a researcher and activist based at the self-managed ESC Atelier, and foundermember of LUM (Free Metropolitan University) in Rome. He has been founder-member of the projects Edufactory and Uninomade, and is the initiator of Studio Roma in Rome and of Studio 14 in Athens. He holds a PhD in Critical Management and Political Economy from Queen Mary University of London, and has written on the critique of the political economy of knowledge, and on the organization and strategy of transnational social movements.

\section{ADDRESS:}

La Sapienza,

University of Rome,

Piazzale Aldo Moro, 5,

00185 Rome, Italy

EMAIL: paolo.dox@gmail.com

CITATION: Do, Paolo. 2015. „Towards a Global Regime of Higher Education.” Praktyka Teoretyçna 4 (18): 44-61.

DOI: $10.14746 /$ prt.2015.4.2 